\title{
Interventions to Scale-Up Palmpreneurship in Tamilnadu
}

\author{
P.Malarvizhi
}

\begin{abstract}
Sustainable agricultural practices being the need of the hour, the younger generation should explore and exploit the natural potentialities of India with the emerging and enabling technologies. It is up to them to convert those potentials into opportunities and become successful agripreneurs. Agriculture based business opportunities are on the verge of evolution and revolution in India with increased awareness about healthy way of living. In Tamilnadu, amidst the conditions of unreliable climate, dependency on neighboring states for water resources and heavily debt burdened farmers, palm tree based micro business opportunities should be harnessed to its fullest potential, thus boosting the rural economy of the state.

This paper proposes the use of blockchain technology during the plantation of palm trees, manufacturing and supply chain management of edible palm products like palm jaggery and palm sugar so as to add value to them and enhance their domestic and export market value. A need gap analysis has been done to facilitate vibrant development of palmpreneurs in Tamilnadu with the help of blockchain technology.
\end{abstract}

Key Words: Palm tree, palm products, palm artisans, palmpreneurs, blockchain technology.

\section{INTRODUCTION}

Agriculture is the primary source of livelihood for about 58 percent of India's population. As per union budget 2018-19, allocation of Rs. 57,600 crores (US\$ 8.9 billion) was made for the agriculture ministry. In India, agriculture accounts for nearly $18 \%$ of the GDP and it is the second largest producer of agricultural products. India produces 7.68 percent of total global agricultural output. It is in this same country with such a background, despite of central government's multi-pronged approach to improve the income and social security of farmers, over 12,000 suicides are reported in the agricultural sector every year since 2013. Farmer suicides account for approximately 10\% of all suicides in India. There may be various reasons such as monsoon failure, climate change, surge in input costs, high debt burdens, lack of direct integration with the market, government's urban consumer driven economic policies etc.

Shifting from our nation's perspective in general to Tamilnadu state in particular, the farmers here are largely depending upon the neighboring states for water requirements of their agricultural activities amidst the plenty of disputes in sharing the water that leads to litigations. Alongside the ever failing monsoons and its uncertainties, the Tamilnadu farmers are the worst affected, burdened with heavy debts and continue to sustain unforeseen and undesired losses.

Revised Version Manuscript Received on August 19, 2019.

Dr. P.Malarvizhi, Assistant Professor,Post Graduate and Research Department of Commerce,Chevalier.T.Thomas.Elizabeth College for Women,Chennai, Tamilnadu, India.(Email: malar_mvs@yahoo.co.in)

\section{NEED FOR THE STUDY}

In this scenario, as older generation is retiring from farming and younger generation, hesitant and reluctant to engage in farming for their livelihood, it is pertinent to revamp the situation by exploring and augmenting the region specific natural resources. Indian youth should think differently and take risk to start new ventures in the form of agripreneurshiputilising the potential of their region, without disturbing the nature. Tamilnadu, subject to vagaries of fluctuating climatic conditions and farmers burdened with heavy debt, plantation of palm trees should be increased in the state. The weather resilient palm tree, known as the state tree is very much suitable for the tropical climate of the region.

This paper throws open the potentiality embedded in the palm tree industry and highlights the vast scope for developing palmpreneurship through blockchain technology, thus, mooting a small step towards alleviating poverty in rural areas of Tamilnadu.

\section{OBJECTIVES OF THE STUDY}

1. To outline the benefits and potentiality of palm tree industry

2. To analyse the need gap existing in the development of palmpreneurs

3. To highlight Blockchain technology as a tool to add value to the edible palm trade

\section{LIMITATIONS OF THE STUDY}

- This study is based on data collected from Central Palm Products and Palmgur Institute(CPPPI)- Khadi and Village Industries Commission(KVIC) project reports, interview with their field workers, other newspapers, journals and websites

- The discussions done in this study is from region specific perspective of Tamilnadu state in India

\section{RESEARCH METHODOLOGY}

Descriptive research method applied in this research. It is a descriptive one, in the sense that the researcher has reported on variables that are conducive for palmpreneurship development in Tamilnadu.

\section{REVIEW OF LITERATURE}

Rabeesh Kumar Verma, Alok Kumar Sahoo et al., (2018), "Opportunities in agripreneurship in India: Need, challenges

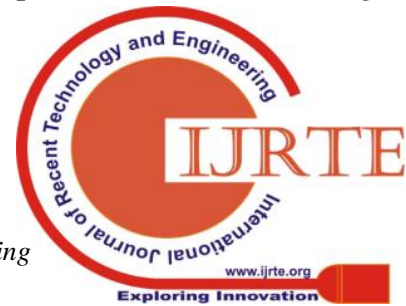


and future prospects", highlights the dire need of making suitable policies and frameworks with action plans for achieving the target of agripreneurship development with establishment of several support systems to incubate the agripreneurs in rural India.

TouficHirbli, "Palm oil traceability: Blockchain meets supply chain", has proposed solution leverages blockchain and IoT technologies to enable the traceability of palm oil. Blockchain is proposed as a data management system to provide traceability to sustainable palm oil products throughout the value chain, taking into account the analyses from a technology, process and people perspective.

\section{POTENTIALITY OF PALM TREE INDUSTRY}

Since the sangam era, palm tree, hailed as the state tree, also refered to as karpagavruksham, have been rooted in the cultural and social life of Tamils. These trees are known for preventing soil erosion and augmenting groundwater table. They are capable of growing in the places with high humidity waves and dry sands; even in such places, they bear the disadvantages and give benefits. With the ever failing monsoon and debt burden, it would be a safe and better prospective option for Tamilnadu farmers to plant varieties of weather resilient palm trees in their lands, which never depend upon monsoon or irrigation, and that is the beauty and specialty of palm trees.

The weather-resilient palm trees can provide 180 litres of tender palm water, $25 \mathrm{~kg}$ of palm jaggery, $16 \mathrm{~kg}$ of palm sugar, $10 \mathrm{~kg}$ of firewood and $10 \mathrm{~kg}$ palm leaf besides $20 \mathrm{~kg}$ palm fibre in a year. According to the Tamilnadu agricultural university, it is estimated that there are 8.59 crores of palm trees in India, of which 5.10 crores are in Tamilnadu. If nearly 75 percent of these trees are used for productive purpose, it would give employment to millions of people and the total production would be nearly million tonnes of palm gur and other palm based products.

Palm gur with its characteristic aroma and flavor is one of the traditional natural sweeteners. It was abundantly utilized in Tamilnadu until a couple of decades ago and palm tree finds a mention in the Government of Tamilnadu symbol also. There are traditional tappers belonging to a specific community in the southern parts of Tamilnadu as well as sporadically located in other parts of the state as well. The indigenous artisans, for ages, are engaged in this activity and are tapping, using traditional method of climbing palm tree to get sweet neer which is again processed to manufacture palm gur, palm sugar, palm candy, palm concentrate etc. and other value added products using palm gur as a sweetener. Moreover, to attract the younger generation, ice cream from ice apple(nungu) could also be initiated, as done in Vietnam and Cambodia. Besides this neera and its diverse products and derivatives, these magnificent palm trees offer so much to mankind in many ways, where its roots, trunk, leaves, fibres, saplings, fruits, each in its own intrinsic way fulfill man's economic, social and aesthetic needs. Nothing in these humble palms is ever wasted, as each part serves some useful purpose either as edible or non-edible products. So, with proper government supported schemes, policies and enabling technologies, there is ample scope for raising the domestic as well as export status of palm trade and palmpreneurs in Tamilnadu.

\section{THE NEED GAP EXISTING IN THE DEVELOPMENT OF PALMPRENEURS}

In spite of the advantages bestowed by Mother Nature in Tamilnadu, the state tree has been fast disappearing due to rampant felling and neglect due to lack of climbers. The traditional artisans and their families are drifting away to other trade due to its economic non viability compared to alternative employment opportunities and lack of better price etc. The following analysis highlights the steps to be taken to avert this situation and promote a congenial environment for development of palmpreneurs. This analysis is done from the point of scaling up the domestic and export status of the palm trade and raising the earning capacity of the small scale palmpreneurs considering its viability and sustainability in rural Tamilnadu.

$>$ The traditional method of climbing palm trees is cumbersome, because of which the youngsters are not interested in the trade; as the older ones are retiring, others are drifting away from the trade due to its drudgery and the economic non viability. Improvised climbing devices can be provided at economical cost by the government.

$>$ The tappers collect neera in the collection pot which is unfermented by coating lime to the earthen pot. This neera collection should be streamlined for marinating standards and prevention of spoilage.

$>$ The collected neera is filtered and poured in the galvanized iron pan and boiled in the traditional firing stoves to condense the liquid neera to a particular consistency. The condensed matter is poured into the earthen dies dug on the ground and layered with a cloth for allowing it to become solid on cooling. This process is mostly done in open in the road side, leaving scope for contamination. It is very unhygienic and the process of gur making is primitive and susceptible to capture foreign matter in the end product as it is exposed to open atmosphere. Moreover the materials used are galvanized iron, worn out soiled clothes as well as inappropriate additives like castor seeds etc.; hence as such there is no real value chain involved in the traditional processing of palm products. Community processing with integration of blockchain technology will enable to improve the quality, efficiency and standardization of the product as well as better market reach and consolidation.

$>$ Packing of the final product in palmyra leaf baskets and other open storage and transportation is susceptible to contamination and deterioration in the quality as well as the shelf life. The shelf life of neera should be extended by improved collection and storage devices like insulated containers from the farm to the factory. Refrigerated vehicles should be used for transportation, not only to extend the shelf life, but also to extend the place and time utility for neera sale widely.

$>$ The palm workers are subjected to exploitation by the middlemen. At the present level, the marketing of palm gur is entirely at the mercy of the middle men, as the tapper is wholly dependent on him for his merchandise and takes advance from them during off season, making it a closed sale or otherwise a distress sale. The middlemen buy the palm

Published By:

Blue Eyes Intelligence Engineering

\& Sciences Publication 
products at a cheaper rate from the palm artisans and market it for quite high prices, thereby easily exploiting them by using their weaknesses. Formation of clusters will play a vital role due to its volume of production and institutional framework and will arrange to bypass the local trader and arrange for the direct marketing or to cut short the marketing channel, thereby directly catering to the end user. Further value addition of many activities will also be taken up. Government also need to create regulatory markets for the palm products to stop the exploitation by the middlemen.As envisaged in "Strategy for New India@ $@ 75$ " released by NITI Aayog in November 2018, emphasis must shift to converting farmers to agripreneurs by further expanding e-National Agriculture Markets(e-NAMs). The creation of a unified national market, a free export regime and abolition of the Essential Commodities Act are essential for boosting agricultural growth.

$>$ The palm industry activities are traditional, passed on from one generation to another, but currently being neglected or avoided by the younger generation due to the risk involved in it. Palm tree climbing is also seen as an undignified job and social bias is associated with it. Thereby, this industry is gradually declining day by day, in spite of increasing demand and awareness about the eco friendly health benefits of various palm products. To prevent such a decline and considering the potentiality of the industry, the government should introduce palm industry courses in the industrial training institutes, thereby more number of educated youth will come forward to undertake the activities of palm industry, which is commercially viable and profitable. So far no such initiative has been taken in our country and it is high time to introduce palm industry courses under the purview of Industrial Training Institutes. There is no need for making any investment for this purpose, as there are plenty of well grown palm trees available all over Tamilnadu and India, which are sufficient to commence the activities in each districts. Special attention in the form of guidance, creating awareness about the palm industry and its capabilities of generating income and the cooperation are the only need of the hour.

$>$ With the increasing awareness about edible palm products like palm gur, palm sugar etc., it has become a common sight of display and sale of unlabelled palm products on Chennai city roads. Measures should be initiated to label them with effective information as to its quality and price. This can positively influence its domestic and export

\section{BLOCKCHAIN TECHNOLOGY AS A TOOL TO ADD VALUE TO THE TRADE IN EDIBLE PALM PRODUCTS\& RESULTS}

Considering the potential for boosting the export market for palm products, integration of technology in this industry will bring the desired result. The fragmented artisans should be consolidated into clusters and brought under an institutionalized framework. The artisans brought under such framework should be trained to adopt Blockchain technology. The integration of this technology will eliminate the gaps as discussed under objective 2 above, during collection of neera, processing of neera into palm gur, its storage and transportation, fixation of reasonable price, market success.

functioning of regulatory authority, and finally, packing and labeling. Thus, blockchain technology will bring transparency in the functioning of palm artisans and facilitate value addition to the traditional processing method as well as to the supply chain.

The following exhibit shows the proposed transformation of edible palm products value chain into digital value supply chain, enabled by Blockchain technology:

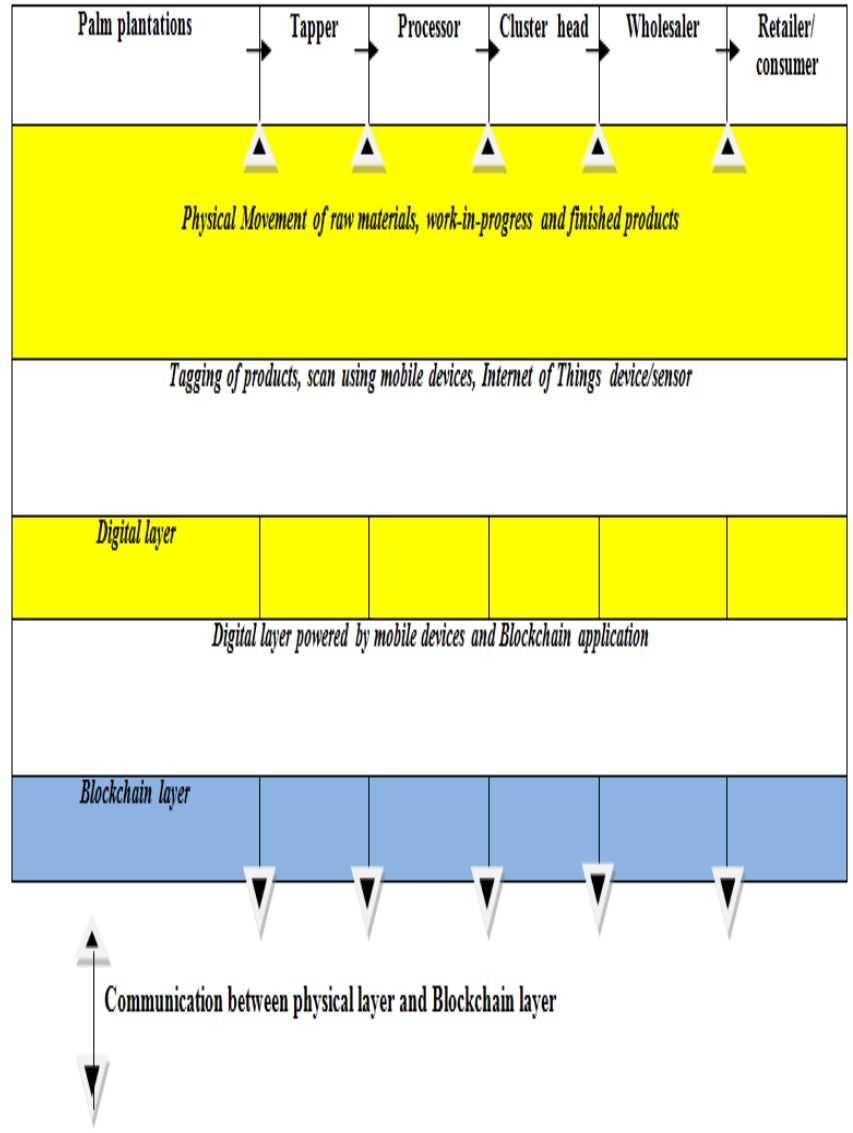

As shown in the above exhibit, a tamper-proof, encrypted database can be made to reside with every participating entity or node in the value chain. Each of these nodes will precisely contain the same transaction record, be it the tapper, processor, cluster head, wholesale trader, retailer or consumer, thus every transaction in the value chain will exist in every node. Transaction data is encrypted and stored in containers of information called "blocks" which are pushed out across all nodes. Business rules, known as "smart contracts" can also be embedded into the system that will consequently apply, "if this, then that" logic, making actions free of human arbitration. This technology will bring about transparency in the various stages of manufacturing of edible palm products such as collection of neera under controlled conditions, chilling, processing, packaging, labeling, transporting and branding.

Blockchain technology will facilitate the monitoring of temperature and humidity during processing, storage and transportation, thus efficiently identifying poor batches. Blockchain's smart contracts can then enforce rules 
that automatically grade products in a way that only those that meet the highest standards enter the market for human consumption. Retailers also can present the end product with identifiers such as QR codes, enabling buyers to view the product's journey back to its source. In the age of environmentally aware and health-conscious consumer, this level of transparency will usher in a new era of trust and brand loyalty that is of great value to micro palmpreneurs in a competitive domestic as well as export market.

Adoption of this technology will ensure ideal, hygienic conditions in the preparation of edible palm products and result in the elimination of poor and substandard processing techniques. With the rising demand for palm products, usage of blockchain technology can create trust and accountability among market players. This will not only have a transformative impact on the edible palm trade by creating transparency in the supply chain but also create value for all its stakeholders.

\section{CONCLUSION}

The rural economy of Tamilnadu can be uplifted by focusing on the commercial potentiality, enviro-viability and sustainability of palm products, for which market potential is immense. With the integration of blockchain technology in the value chain as narrated above, its growth can be easily accelerated and achieved, resulting in palmpreneurship development. The adoption of blockchain technology will improve the competitiveness of palmpreneurs through product standardization, differentiation and food safety required in a competitive environment, along with better access to credit and market opportunities.

To conclude in the words of Mahatma Gandhiji, (Brindawan / $3^{\text {rd }}$ May 1939), "Neera can be converted into jaggery, as sweet as honey itself. This jaggery is superior to cane jaggery. Cane jaggery is sweet, but palm jaggery is sweet and delicious; it can be produced worth crores of rupees. Palmgur gives mineral salts too. Where there are palm trees, this jaggery can be easily produced. This is the way of vanishing poverty from our land. This also is an antidote to poverty".

\section{REFERENCES}

1. A book on Palmgur Industry, Central Palmgur and Palm Products Institute, Chennai

2. http://www.newindianexpress.com/2018/apr/22

3. NITI Aayog, Strategy for New India@75, November 2018

4. Rabeesh Kumar Verma, Alok Kumar Sahoo et al., "Opportunities in agripreneurship in India: Need, challenges and future prospects", RashtriyaKrishi, Volume 13, Issue 1, June, 2018, pp.no. 69-72, e ISSN-2321-7987

5. The News Minute April 24, 2018

6. timesofindia.com, June 11, 2017

7. TouficHirbli, " Palm oil traceability: Blockchain meets supply chain", https://ctl.mit.edu 